Михаил Комин и Александр Вилейкис, Connections QJ 15, № 1 (2016): 64-80 http://dx.doi.org/10.11610/Connections.rus.15.1.04

\title{
«Хорошие» и «Плохие» инвестиции: все, что вы всегда хотели знать об украинских командирах, но боялись спросить
}

\section{Михаил Комин и Александр Вилейкис}

Санкт-Петербургский государственный университет, Университетская набережная, 7-9, Санкт-Петербург 199034, Россия, http://english.spbu.ru/

\begin{abstract}
Резюме: Военный конфликт в Юго-восточной Украине дает огромные возможности для исследований в самых разнообразных областях и в зоне продолжающихся боевых действиях со всеми социальными последствиями для всех его участников. В этой статье рассмотрены некоторые из ключевых для этой войны вопросов: почему добровольческие батальоны совершают некоторые вредные и негуманные действия и что дальше можно сделать для предотвращения насилия после войны. Так как война создает большие районы без всякого контроля, имеют место огромные нетрансферабельные инвестиции, случаи пыток гражданских лиц и т.д. Авторы пытаются объяснить, какие условия могут оказывать влияние на поведение батальонов, и что правительства должны делать после окончания войны.
\end{abstract}

Ключевые слова: российско-украинский конфликт, психология насилия, прокси-война, нетрансферабельные инвестиции, добровольческие батальоны.

\section{Введение}

Военный конфликт на юго-востоке Украины создает огромное поле для исследований в самых разнообразных областях, и он привел к появлению локальной зоны, в которой продолжаются боевые действия, со всеми социальными последствиями для людей, находящихся в зоне конфликта. В первые месяцы войны на Украине было сформировано большое число добровольческих батальонов, которые стали одними из ее главных игро- 
ков. Как показали предшествовавшие локальные конфликты на постсоветском пространстве, например Чеченская война и Нагорно-Карабахский конфликт, большинство таких конфронтаций не завершаются при разрешении ситуации руководством участвующих сторон. Поскольку многие из этих конфликтов имеют характер локальной гражданской войны, в самой зоне конфликта происходят определенные политические, социальные и культурные сдвиги. ${ }^{1}$ Участники, добровольцы батальонов, которые оказываются вовлеченными в конфликт на продолжительный период времени, могут по окончании горячей фазы конфликта в общественном сознании трансформироваться от защитников отечества в незаконные военизированные группировки. Как раз факт добровольного участия этих бойцов в вооруженных действиях усложняет их последующее возвращение в гражданскую жизнь. Это имеет место, особенно если батальон приобрел существенный политический вес в ходе конфликта, и после его окончания стремится к сохранению своего влияния на ситуацию в местной политике. Как видно из примера конфликта в Мукачеве, сейчас эта проблема приобретает непосредственное значение для украинской политики и национальной безопасности. ${ }^{2}$

Вот почему настоящее исследование посвящено изучению причин и последствий этой проблемы и явления, состоящего в так называемых «нетрансферабельных» инвестициях, сделанных участниками этих батальонов. ${ }^{3}$ Основной вопрос, поставленный здесь, это: как личностные и социальные характеристики командира добровольческого батальона оказывают влияние на уровень общих нетрансферабельных инвестиций? В этом исследовании подвергаются проверке две гипотезы.

Гипотеза 1. Объем нетрансферабельных инвестиций, сделанных в целом добровольческим батальоном, напрямую зависит от командира этого батальона.

Гипотеза 2. Готовность командира делать нетрансферабельные инвестиции зависит от его личностных и социальных характеристик.

В данном исследовании изучается следующий эмпирический материал: добровольческие батальоны, сформированные во время конфликта Украина-Россия в 2014-2015 годах; персональные и социальные характеристики командиров этих батальонов; действия батальонов во время конфликта; отражение в СМИ их деятельности; и официальная оценка украинскими властями их деятельности.

1 Stathis N. Kalyvas, The Logic of Violence in Civil War (Cambridge: Cambridge University Press, 2006).

2 Ivan Lyubimov, "Extractive Institutions, Closed Borders and Economic Development," доступно на http://papers.ssrn.com/sol3/papers.cfm?abstract_id=2543169.

3 Tudor Lubenov, Ivan Marinov, Emiliya Velizarova, "Risk of Flooding: Activities, Parameters and Regional Peculiarities (Case study: Varbitsa watershed basin, Bulgaria)," Glasnik Srpskog geografskog drustva 89:4 (2009): 75-83. 
Для этой цели были использованы следующие исследовательские методы:

- Контент-анализ открытых украиноязычных и русскоязычных медиа источников в Интернете;

- Контент-анализ официальных документов Министерства обороны Украины, администрации Президента Украины и постановления украинского правительства;

- Корреляционный анализ установленных показателей и характеристик, основанный на данных, полученных при контент-анализе;

- Метод моделирования социальных процессов, основанный на социальных и политических теориях и конвенциях.

Для проверки первой гипотезы авторы данной статьи обращаются к классическим работам по взаимодействию между лидером и данной социальной группой.

\section{Социологическая и психологическая валидация}

В своей работе «Психология зла», изучая явление нетрансферабельных инвестиций, сделанных американскими военнослужащими в Абу Граибе, Филипп Зимбарго пытается отбросить классическое представление, что склонность к садистскому насилию является внутренним отклонением человеческого существа. ${ }^{4}$ По его мнению, скорее это редкость и применимо только к 5 \% людей. ${ }^{5}$ Исследователь утверждает, что каждый человек даже наиболее нормально выглядящие личности - способны проявлять жестокость и иметь внешние проявления насилия, если налицо некоторые факторы. Основная проблема, которую исследует Зимбарго, состоит в том, что военнослужащие совершали такие действия против военнопленных потому, что они считали, что это и есть наиболее полное осуществление предписанной им социальной роли; точнее, они считали, что избивая и унижая военнопленных, они смогут получить от них полезную информацию, и таким образом, получить одобрение своей командной структуры. ${ }^{6}$

Основываясь на эмпирических данных, полученных во время стэнфордского тюремного эксперимента, на данных о случае Абу Граиб, исследователи пришли к заключению, что нормальные люди начинают использовать насилие, если одновременно налицо четыре условия: (1) анонимность; (2) безнаказанность (освобождение от ответственности); (3) образ, вызывающий ненависть, который можно связать с жертвами насилия и (4) окру-

Philip G. Zimbardo, "The Psychology of Evil," Eye on Psi Chi 5 (2000): 16-19.

Там же.

6 Mark Danner, Torture and Truth: America, Abu Ghraib, and the War on Terror (New York: New York Review of Books, 2004). 
жение, отличающееся жестокостью. ${ }^{7}$ Для проявления наиболее жестоких форм насилия, в число которых входят мародерство, унижение узников и массовые убийства гражданских лиц, важно, чтобы все эти условия выполнялись одновременно и полностью.

Как можно заметить, три из четырех условий имели место в конфликте в Юго-восточной Украине. Образ врага действительно существует, окружение требует жестокости, маски лыжников и камуфляжи обеспечивали достаточную степень анонимности. Поэтому, единственным отличием между батальонами, которые делали нетрансферабельные инвестиции, и другими, является четвертый фактор: безнаказанность. Безнаказанность, освобождение личности от ответственности, в сочетании и само по себе создает дополнительную мотивацию для осуществления таких действий в качестве наиболее полного исполнения социальной роли (воина), в которой она оказалась. Поэтому, чем более насильственно ее поведение, тем лучше она проявляет требуемые качества, точнее более успешно, чем окружающие. Личность способна совершать действия, осуждаемые обществом, когда она освобождена от ответственности за такие действия. В такой момент она верит, что даже убийство другого человека может принести ей максимальную выгоду в ее социальной группе.

В полевых условиях гражданской войны, однако, только командиры могут обеспечить военнослужащим такую безнаказанность. ${ }^{8}$ Поэтому уровень нетрансферабельных инвестиций бойцов зависит от персональных и социальных особенностей командира. По существу, командир батальона становится "местным диктатором», фигурой, которая создает новую социальную реальность вокруг батальона. Командир является единственным источником приказов, которые предписывают солдатам определенные социальные роли. На гражданской войне вертикальный контроль над командиром слаб, и чаще всего вообще отсутствует контроль со стороны более высоких уровней командования. Но даже, если такой контроль и существует, в определенные моменты его исключительно трудно осуществлять, поскольку в условиях постоянных боевых действий принятие оперативных решений является обязанностью командира батальона.

Эксперимент, проведенный другим социальным психологом, Стэнли Милграмом, подтверждает описанную выше идею, основываясь на человеческой психологии. "При этом эксперименте, в котором испытуемое лицо подчиняется приказам другого субъекта (исполняет свою роль), обнаруживаются шокирующие результаты. Эксперимент состоял в симулированном обучении, при котором субъект задавал вопросы, и в случае не-

7 Craig Haney, Curtis Banks, and Philip G. Zimbardo, "Study of Prisoners and Guards in a Simulated Prison," Naval Research Reviews 9 (1973): 1-17.

8 Philip G. Zimbardo, "The Human Choice: Individuation, Reason, and Order versus Deindividuation, Impulse, and Chaos," Nebraska Symposium on Motivation 17 (1969): 237-307.

9 Stanley Milgram, Das Milgram-Experiment (Reinbek: Rowohlt, 1974). 
правильного ответа нажимал на кнопку, что вызывало удар тока. Когда показания прибора достигали «уровня XXX» (смертельная доза), за стеной слышались крики и просьбы прекратить, но руководитель эксперимента настаивал на продолжении экзамена. В итоге, две трети психологически нормальных людей были способны продолжать до точки “убийства» экзаменуемого субъекта. Этот эксперимент показывает, что наличие факторов, идентифицированных Зимбарго, и желание личности выполнять свою социальную роль настолько хорошо, насколько это возможно, могут привести к тому, что личность начнет совершать нетрансферабельные инвестиции. Ключевым фактором для совершения таких инвестиций является безнаказанность; в данном случае «одобрение» со стороны личности, которая обладает более высоким социальным статусом в данной группе. Командир добровольческого батальона в Юго-восточной Украине полностью соответствует этим критериям.

Прямая связь между личными качествами командира и количества нетрансферабельных инвестиций, сделанных батальоном, можно так же рассматривать и с социологической точки зрения. Изложение этой идеи можно найти в работе американского социолога Эрвина Гофмана, посвященной формированию настроений в военных частях США во время Второй мировой войны. ${ }^{10}$ Гофман пытался найти корреляцию между поведением военнослужащих на поле боя и на территории, которую они оккупировали, и определенными социальными и культурными характеристиками самих военнослужащих. Начальная гипотеза была подобна общепринятой догме: до этого социологи считали, что ключевым фактором в поведении подразделений были персональные черты преобладающего большинства солдат. То есть, если в одном подразделении были собраны большое число преступных или маргинальных субъектов, для такого военного подразделения выше вероятность, что оно будет делать «плохие вещи», к примеру, мародерствовать.

Работа Гофмана ясно показала, что эта гипотеза неверна. Даже подразделения, состоящие в основном из преступных субъектов, демонстрировали героизм на поле боя и строго следовали приказам командиров. Тогда как другие подразделения, которые как будто были менее склонны к совершению «плохих дел», на самом деле совершали серьезные преступления. Наилучшим примером, подкрепляющим эту гипотезу, является $101^{\text {-ая }}$ воздушно-десантная дивизия «Кричащие орлы», которая в 1944 году состояла в основном из преступников, но во время операции Bastogne показала себя исключительным образом. ${ }^{11}$

Кроме того, Гофман предлагает альтернативную теорию, которая была эмпирически подтверждена его исследованием. Настроения и боевые

10 Erving Goffman, Asylums: Essays on the Social Situation of Mental Patients and Other Inmates (New Brunswick, NJ: Aldine Transaction, 1961).

11 Mark Bando, $101^{\text {st }}$ Airborne: The Screaming Eagles at Normandy (Minneapolis, MN: Zenith Imprint, 2011). 
способности военной части определяются не преобладающим числом солдат, а одним или двумя акторами, которые часто переносят образ своего поведения на все подразделение. Если в подразделении появляется личность, которая начинает активно заставлять своих товарищей относиться с жестокостью к местному населению, и первая начинает действовать таким образом, существует большая вероятность, что другие члены этого подразделения воспримут идентичное отношение.

Еще одно доказательство этой теории присутствует в эксперименте французского социального психолога Сержа Московици, показавший, что активное меньшинство заставляет других членов группы отказаться от своей позиции. ${ }^{12}$ В эксперименте изучалась способность активного меньшинства заставить согласное или пассивное большинство принять их точку зрения. Результаты показали, что даже небольшая, но активная группа агитаторов способна заставить окружающих воспринять ее точку зрения (часто объективно неверную). Как раз это явление делает изучение личности командира настолько важным, поскольку в добровольческом батальоне (в отличие от регулярной армии) командир является главным источником идей для целого подразделения. Он формирует батальон, что означает, что он передает свои ценности остальной части подразделения.

Таким образом, с учетом вышеупомянутых факторов, анализ причины того, что батальон делает нетрансферабельные инвестиции, требует понимания причин для предприятия таких действий самим командиром. Представленная здесь гипотеза состоит в том, что личностные и социальные характеристики командира оказывают влияние на этот процесс. Эта проблема, как и сама концепция нетрансферабельных инвестиций, рассматривается в следующем разделе.

\section{Теория нетрансферабельных инвестиций}

Термин «нетрансферабельные инвестиции» был введен политологом Миланом Своликом в его статье, «Моральная опасность авторитарных репрессий и судьба диктаторов». ${ }^{13}$ Он утверждает, что диктатор в авторитарном режиме совершает некоторые действия, которые с одной стороны направлены на усиление его влияния (преследование оппозиции, коррупция, покровительство своих приятелей и так далее) и, с другой стороны, увеличивают вероятность, что после устранения от власти он подвергнется преследованию (трибунал, тюремное заключение, смертная казнь). Сволик называет нетрансферабельными инвестициями те действия диктатора, которые одновременно соответствуют этим двум условиям, т.е. инвестиции, которые автократ может использовать только пока он находится у власти. Нетрансферабельные инвестиции аналогичны жульничеству в не-

12 Serge Moscovici, Psychologie sociale des relations à autrui (Paris: Nathan, 1994).

13 Milan W. Svolik, "Moral Hazard in Authoritarian Repression and the Fate of Dictators," The Political Economist 13:2 (2011): 7-9. 
которой абстрактной игре, которое позволяет быстро получить максимальный выигрыш, но в то же время чревато жестоким наказанием.

Развивая эту тему, русский политолог и экономист Иван Любимов применяет логику "дилеммы диктатора» к личностям, которые обладают существенной степенью авторитарного контроля в определенных условиях, которые ограничены по времени и наличии ресурсов. ${ }^{14}$ В качестве примера автор приводит военных командиров в Аргентине, которые подвергали солдат репрессиям и грабили гражданское население, не боясь преследования, пока они контролировали определенную территорию. В такой ситуации местные автократы становились «перманентными бандитами», которые стремились к увеличению своего богатства, совершая нетрансферабельные инвестиции. ${ }^{15}$

В таких случаях личность сталкивается с дилеммой: совершая незаконные или тайные действия, она получит множество выгод и привилегий. Однако, если она потеряет власть, риск возмездия увеличивается. Чтобы принять решение, личность должна прогнозировать как будет развиваться ситуация и оценить вероятность и серьезность преследования при наиболее неблагоприятном сценарии.

В рамках этого исследования предполагается, что условия гражданской войны ставят пред командирами военных подразделений подобную дилемму, поскольку при слабом надзоре со стороны вышестоящих властей и боевых действиях, имевших место в его собственной стране, командир добровольческого батальона имеет всю полноту власти на территории, на которой действует его батальон. Таким образом, здесь можно применить теорию нетрансферабельных инвестиций для изучения процессов, которые протекали на Украине с мая 2014 по май 2015 года. Как раз в этом периоде исполнительная власть и высшее командование Украины осуществляло наименьший контроль за действиями батальонов. ${ }^{16}$ Поэтому эмпирическая часть исследования базируется на контент-анализе СМИ, открытых интернет источников и официальных документов государственных органов Украины, которые описывают и характеризуют действия батальонов и их командиров в этот период.

В качестве нетрансферабельных инвестиций были приняты следующие действия командиров батальонов:

1.Документированное аморальное поведение в отношении пленников (унижения, насилие, пытки), а также отказ, в принципе, брать пленных.

14 Иван Любимов, «Эффект диктатуры», Слон, 9 July 2015, доступно на https://slon.ru/posts/53823.

15 Martin C. McGuire and Mancur L. Olson, "The Economics of Autocracy and Majority Rule: the Invisible Hand and the Use of Force," Journal of Economic Literature 34:1 (1996): 72-96.

16 Gerhard Simon, "Collapse and a New Beginning: The Ukrainian Revolution and Its Enemies," in Conflict, Crisis, War, a special issue of Osteuropa 64 (2014): 5-6. 
2.Документированное аморальное поведение в отношении местных гражданских лиц (грабеж, похищения, насилие).

3.Использование ресурсов батальона для собственного обогащения (шантаж и нападения на бизнес-объекты на данной территории, участие в контрабанде, участие в коррупционных схемах при осуществлении поставок ресурсов для батальона и т.д.).

4.Агрессивные высказывания в отношении других проукраинских сил.

5.Пренебрежение к жизни солдат батальона, покидание их в опасности и т.п.

Важно отметить, что третий пункт был наиболее распространенной нетрансферабельной инвестицией, которую делали командиры украинских добровольческих батальонов в течение вопросного периода. В соответствии с теорией, изложенной ранее, в данной работе все другие действия командиров батальонов рассматриваются как трансферабельные инвестиции, т.е. действия, которые выгодны командиру батальона даже если он потеряет статус такового.

\section{Причины и модель реализации нетрансферабельных инвести- ций полевыми командирами добровольческих батальонов во время конфликта в Юго-восточной Украине}

Вторая гипотеза этого исследования включает следующий вопрос: что мотивирует командиров добровольческих батальонов делать нетрансферабельные инвестиции? Чтобы найти ответ на этот вопрос, была применена «Теория авторитарной личности», которая описана группой исследователей. $^{17}$

Используя методы психологического анализа и ассоциативного тестирования, по $\mathrm{F}$ шкале можно определить, в какой степени данная личность способна стать «местным диктатором». ${ }^{18}$ Авторы теории идентифицируют четыре основные причины для такого процесса: (1) персональная история данной личности, (2) ее личностные характеристики, (3) степень удовлетворенности своим нынешним статусом и (4) ее нынешнее социальное положение.

В рамках нашего исследования эти критерии были операционализированы, что привело к следующим показателям:

1.Возраст человека

17 Jos D. Meloen, "The F-Scale as a Predictor of Fascism: An Overview of 40 Years of Authoritarianism Research," in Strength and Weakness, edited by William F. Stone, Gerda Lederer, and Richard Christie (New York: Springer, 1993), 47-69.

18 Jos D. Meloen, L. Hagendoorn, Q. Raaijmakers, and L. Visser, “Authoritarianism and the Revival of Political Racism: Reassessments in the Netherlands of the Reliability and Validity of the Concept of Authoritarianism by Adorno, et al.," Political Psychology 9 (1988): 413-429. 
2.Уровень образования и его профессия

3.Рабочий опыт, карьера и трудовая биография до участия в конфликте (особое внимание следует обращать на то, есть ли у человека криминальное прошлое)

4.Участие в общественной и политической жизни до участия в конфликте

5.Социальный статус личности до участия в конфликте

6. Карьера и трудовая занятость человека после участия в конфликте

7. Социальный статус после участия в конфликте.

Кроме того, основываясь на пункты 3 и 4, авторы сформулировали вторичный категориальный показатель 8, а на основе данных по пунктам 2, 3 и 5 получили вторичный категориальный индикатор 9:

\section{8. Склонность человека рисковать}

9.Потребность личности увеличивать свой символический капитал.

Теоретическая логика для введения показателей 8 и 9 основывается на концепции французского социолога Пьера Бурдо о трансформации разных типов капитала и на адаптации этой теории, предложенной современным российским историком и политологом Георгием Дерлугьяном. ${ }^{19}$

Теория трансформации капитала предполагает, что капитал отдельной личности (социальный, политический, экономический или символический) может увеличиваться или переходить из одного вида в другой при определенных действиях. В этом плане, каждый из этих видов капитала требует практической реализации, что заставляет личность предпринимать определенные действия. В своей работе Дерлугьян отмечает, что для большинства людей на постсоветском пространстве характерен высокий уровень символического капитала (высокое образование, широкая эрудиция и высокий уровень интеллигентности), и весьма низкий уровень других видов капитала. Для этих людей данный феномен порождает высокую степень неудовлетворенности своим социальным статусом. Поэтому человек пытается трансформировать свой символический капитал в другие виды капитала - политический, экономический или социальный.

В конфликте в Юго-восточной Украине большинство командиров обладает высоким уровнем символического капитала (образование и высокая степень общественной активности), и поэтому пытаются использовать вооруженный конфликт и свое положение командиров батальонов для трансформирования его в:

19 Georgi M. Derluguian, Bourdieu's Secret Admirer in the Caucasus: A World-System Biography (Chicago: University of Chicago Press, 2005); Georgi M. Derluguian, et al., "Adept Bourdieu in the Caucasus. Sketches for the Biography in the World-System Perspective," Directmedia (2013). См. также Pierre Bourdieu, "Forms of Capital," in Cultural Theory: An Anthology, ed. Imre Szeman and Timothy Kaposy (Oxford: WileyBlackwell, 2011), 81-93. 
- политический капитал (присоединение к существующей элите)

- социальный капитал (публичное признание, высокий образ в обществе «Защитника Отечества»)

- экономический капитал (персональное обогащение).

Таким образом, потребность трансформировать символический капитал в другой тип капитала становится для командира батальона ключевым мотивом для осуществления трансферабельных или нетрансферабельных инвестиций. В этом смысле, каждый конкретный случай трансформации имеет особые аспекты:

1.В случае, когда символический капитал трансформируется в политический, человек прибегает к нетрансферабельным инвестициям, когда командир - несмотря на свою популярность и политический вес - не вхож в элиту.

2.Когда символический капитал трансформируется в социальный, человек начинает делать трансферабельные инвестиции, когда он ставит увеличение своей личной популярности над военным успехом батальона или сознательно преувеличивает свой вклад и вклад батальона в положительном исходе боев.

3.Любая трансформация символического капитала командира батальона в экономический капитал сопровождается увеличением нетрансферабельных инвестиций, поскольку боевые операции не могут быть направлены на получение прибыли. Любое накопление богатства в таких условиях незаконно и считается обществом неморальным.

Однако, даже если командир не может достичь желаемого уровня капитала, во многих случаях не происходит перехода к нетрансферабельным инвестициям, так как дополнительные персональные и социальные характеристики, которые были операционализированы ранее, оказывают влияние на «готовность» командира совершать «плохие дела».

В эмпирической части этого исследования также анализу подвергается влияние сочетания социальных и персональных характеристик, уровень индивидуальной предрасположенности рисковать и необходимость трансформировать символический капитал в итоговое осуществление нетрансферабельных инвестиций.

\section{Эмпирическая проверка гипотез и резюме классификации}

В настоящем исследовании изучены тридцать из самых больших добровольческих батальонов, которые действовали во время конфликта в Юговосточной Украине. ${ }^{20}$ Надо отметить, что с самого начала из подборки были исключено военное подразделение под командованием одной из

20 Относительно более подробной информации об источниках, выбранных для контент-анализа, смотри Приложение 1. 
основных украинских политических фигур, Дмитрия Яроша, поскольку он существенно отличается от других командиров батальонов и требует анализа с применением совершенно других методов.

В целом, анализу подверглись:

- Береза, Юрий - командир, батальон «Днепр-1»

- Беркелия, Олег-командир, батальон «Кременчук»

- Билецкий, Андрей - командир, батальон «Азов»

- Витко, Артем - командир, батальон «Луганск-1»

- Войцеховский, Богдан - командир, батальон «Киев-2»

- Вольский, Игорь - командир, батальон «Львов»

- Гончаров, Виталий - командир, батальон «Святой Миколай»

- Гуменюк, Александр - командир, батальон «Киевская Русь»

- Дейдей, Евгений - командир, батальон «Киев-1»

- Катрук, Володимир - командир, батальон «Тернополь»

- Колесник, Николай (Микола Колесник) - командир, батальон «Кривбасс»

- Коханивский, Микола - командир, батальон Организации украинских националистов (ОУН)

- Матейченко, Константин - командир, батальон «Артемьевск»

- Мельничук, Сергей - командир, батальон «Айдар»

- Мороз, Руслан - командир, батальон «Винница»

- Онищенко, Руслан - командир, батальон «Шахтерск»

- Писаренко, Александр - командир, батальон «Сич»

- Питскив, Роман - командир, батальон «Чернигов»

- Полищук, Александр - командир, батальон «Ивано-Франковск»

- Портянко, Владислав - командир, батальон «Сичяслав»

- Семенченко, Семен (настоящее имя: Константин Гришин) - командир, батальон «Донбасс»

- Сторчеус, Руслан - командир, батальон «Херсон»

- Тетерюк, Андрей - командир, батальон «Миротворец»

- Фацевич, Александр - командир, батальон «Свитязь»

- Федоренко, Александр - командир, батальон «Полтава»

- Швалия, Николай - командир, батальон «Золотые ворота»

- Шевченко, Вячеслав - командир, батальон «Кировоград»

- Шестаков, Сергей - командир, батальон «Шторм»

- Яголенко, Андрий - командир, батальон «Слобожанщина»

- Янголенко, Сергей - командир, батальон «Харьков». 
О каждом из командиров была собрана информация по показателям, перечисленным выше. Полученные данные были дигитализованы и затем был использован корреляционный анализ для определения влияния каждого фактора на предрасположенность командиров делать нетрансферабельные инвестиции.

Полученная зависимость представлена в Таблице 1. Результаты требуют некоторой теоретической интерпретации и установление причинноследственных связей. Этот процесс будет рассмотрен шаг за шагом.

1. Чем ближе возраст субъекта к 40 годам, тем выше его готовность делать нетрансферабельные инвестиции. Эта корреляция основана на явлении «постсоветский человек», описанном Дерлюджуяном. Поколение 1980-х в постсоветских странах имело сильное ощущение «потерянных возможностей » (после краха СССР и восхода капитализма в 1990х). Одновременно они ищут средства для самореализации, обладают достаточным символическим капиталом и располагают достаточным количеством времени для резкого изменения направления карьерного развития. Во имя развития карьеры они готовы делать нетрансферабельные инвестиции. Совершенно наоборот, более молодое поколение (27-35) не рассматривает нынешний конфликт как свой «последний шанс» и поэтому менее склонны творить «плохие дела». Более старое поколение (47-60) не чувствует себя готовым «рисковать всем».

2.1. Военное образование субъекта уменьшает его готовность делать нетрансферабельные инвестиции. Это устойчивое наблюдение можно объяснить следующим образом: командиры батальонов, которые получили военное (советское) образование, меньше всего воспринимают вооруженный конфликт как источник для персонального обогащения.

2.2. Образовательный уровень субъекта не влияет на его готовность делать нетрансферабельные инвестиции. В целом результаты, касающиеся этой корреляции, варьируют. С одной стороны командиры, которые были более образованными, обладают большим символическим капиталом, и у них большая потребность в трансформировании этого капитала в другой вид. С другой стороны, командиры с более высоким образованием чаще имеют более высокий статус и занимают более высокие позиции в обществе, что означает, что они менее склонны к риску и нетрансферабельным инвестициям.

3. Криминальное прошлое увеличивает готовность к нетрансферабельным инвестициям. Эту связь следовало ожидать. Личности, которые в прошлом совершали преступления, обладают более низким барьером перед совершением «плохих дел», и более высокой готовностью рисковать, что толкает их на осуществление нетрансферабельных инвестиций.

4.1. Участие личности в предпринимательской деятельности увеличивает готовность делать нетрансферабельные инвестиции. Эта связь так же находит объяснение в более высокой готовности к риску, если они принимали участие в деловой деятельности. Надо иметь ввиду, что в пост- 


\section{Таблица 1}

\begin{tabular}{|c|c|}
\hline Фактор & Воздействие \\
\hline Возраст & $\begin{array}{l}\text { - Чем ближе возраст субъекта к } 40 \text { годам, тем выше } \\
\text { его готовность делать нетрансферабельные инве- } \\
\text { стиции. }\end{array}$ \\
\hline Образование & $\begin{array}{l}\text { - Военное образование субъекта уменьшает его го- } \\
\text { товность делать нетрансферабельные инвестиции. } \\
\text { - Образовательный уровень субъекта не влияет на его } \\
\text { готовность делать нетрансферабельные инвести- } \\
\text { ции. }\end{array}$ \\
\hline $\begin{array}{l}\text { Сведения о судимо- } \\
\text { сти }\end{array}$ & $\begin{array}{l}\text { - Криминальное прошлое увеличивает готовность к } \\
\text { нетрансферабельным инвестициям. }\end{array}$ \\
\hline Вид деятельности & $\begin{array}{l}\text { - Участие личности в предпринимательской деятель- } \\
\text { ности увеличивает готовность делать нетрансфера- } \\
\text { бельные инвестиции. } \\
\text { - Участие личности в общественной и политической } \\
\text { деятельности не имеет никакого влияния на их го- } \\
\text { товность делать нетрансферабельные инвестиции. } \\
\text { - Участие субъекта в деятельности служб безопасно- } \\
\text { сти (полиции или разведывательных ведомств) } \\
\text { уменьшает склонность к совершению нетрансфера- } \\
\text { бельных инвестиций }\end{array}$ \\
\hline $\begin{array}{l}\text { Социальный статус } \\
\text { (до конфликта) }\end{array}$ & $\begin{array}{l}\text { - Чем ниже социальный статус человека до кон- } \\
\text { фликта, тем выше его готовность делать нетрансфе- } \\
\text { рабельные инвестиции. }\end{array}$ \\
\hline $\begin{array}{l}\text { Социальный статус } \\
\text { (после конфликта) }\end{array}$ & $\begin{array}{l}\text { - Чем выше социальный статус (карьера, уровень } \\
\text { доходов), которым обладает данная личность в } \\
\text { рамках определенного периода, тем ниже ее готов- } \\
\text { ность делать нетрансферабельные инвестиции в бу- } \\
\text { дущем. }\end{array}$ \\
\hline $\begin{array}{l}\text { Готовность риско- } \\
\text { вать }\end{array}$ & $\begin{array}{l}\text { - Чем выше готовность человека рисковать, тем } \\
\text { выше и его склонность осуществлять нетрансфера- } \\
\text { бельные инвестиции. }\end{array}$ \\
\hline $\begin{array}{l}\text { Трансформирование } \\
\text { символического } \\
\text { капитала }\end{array}$ & $\begin{array}{l}\text { - Чем выше потребность трансформировать симво- } \\
\text { лический капитал, тем выше склонность к осу- } \\
\text { ществлению нетрансферабельных инвестиций. } \\
\text { - Целостный уровень символического капитала, ко- } \\
\text { торым обладает человек, не имеет никакого влия- } \\
\text { ния на готовность осуществлять нетрансферабель- } \\
\text { ные инвестиции. }\end{array}$ \\
\hline
\end{tabular}

советской Украине любая предпринимательская деятельность, особенно в среднем и крупном бизнесе, была связана с увеличенным риском. 
4.2. Участие личности в общественной и политической деятельности не имеет никакого влияния на их готовность делать нетрансферабельные инвестиции. Как и в пункте 2.2, никакой определенной корреляции нельзя обнаружить между общественной и политической ангажированностью командира и его готовностью делать нетрансферабельные инвестиции. С одной стороны, опыт командира в этой сфере увеличивает его символический капитал; с другой стороны, этот символический капитал основан на том, что общество признает некоторые из его качеств и совершение действий, которые общество воспринимает как неморальные, может привести к утрате того, что командир уже имеет.

4.3. Участие субъекта в деятельности служб безопасности (полиции или разведывательных ведомств) уменьшает склонность к совершению нетрансрерабельных инвестиций.

Эта связь объясняется уже существенной степенью кооптирования командира в существующую элиту. При таких обстоятельствах дальнейшая карьера в службах безопасности зависит от того, насколько его деятельность на посту командира отвечает ожиданиям руководства.

5. Чем ниже социальный статус человека до конфликта, тем выше его готовность делать нетрансферабельные инвестиции. Такая связь ожидаема. Командиры, чей доконфликтный статус был весьма невысоким, имеют большие амбиции, чем их коллеги, и нуждаются в большем увеличении своего экономического капитала.

6. Чем выше сочиальный статус (карьера, уровень доходов), которым обладает данная личность в рамках определенного периода, тем ниже ее готовность делать нетрансрерабельные инвестиции в будущем. Эта корреляция свидетельствует об эффективности механизма, с помощью которого командиры батальонов ассимилируются существующей экономической или политической элитой. Раннее кооптирование может служить наградой для более успешных командиров, которые совершают только общественно одобренные действия. Такое кооптирование может служить дополнительным стимулом для других командиров.

7. Относительно связей, имеющих отношение к «склонности к риску» и «потребности трансформировать символический капитал», смотри анализ, приведенный в предыдущем параграфе.

Основываясь на полученных данных и описанных выше связях, мы предлагаем общую классификацию командиров батальонов, разделяя их на три группы в соответствии с уровнем нетрансферабельных инвестиций, которые они делали. Эта классификация показана в Таблице 2.

\section{Заключение}

В этом исследовании была установлена четкая корреляция между персональными и социальными характеристиками командиров батальонов и «плохими делами», совершенными батальоном, далее с уровнем нетрансферабельных инвестиций, сделанных самим командиром. Была 


\section{Таблица 2}

\begin{tabular}{|c|c|c|}
\hline $\begin{array}{l}\text { Высокий уровень } \\
\text { нетрансферабельных } \\
\text { инвестиций }\end{array}$ & $\begin{array}{l}\text { Средний уровень } \\
\text { нетрансрерабель- } \\
\text { ных инвестиций }\end{array}$ & $\begin{array}{l}\text { Низкий уровень нетранс- } \\
\text { ферабельных инвестиций }\end{array}$ \\
\hline \multicolumn{3}{|c|}{ Командиры батальонов } \\
\hline $\begin{array}{l}\text { - Билецкий, Андрей, бата- } \\
\text { льон «Азов» } \\
\text { - Войцеховский, Богдан, } \\
\text { батальон «Киев-2» } \\
\text { - Колесник, Николай (Ми- } \\
\text { кола Колесник), батальон } \\
\text { «Кривбасс» } \\
\text { - Мельничук, Сергей, бата- } \\
\text { льон «Айдар» } \\
\text { - Онищенко, Руслан, бата- } \\
\text { льон «Шахтерск» }\end{array}$ & $\begin{array}{l}\text { - Коханивски, Ми- } \\
\text { кола, ОУн } \\
\text { - Полищук, Алек- } \\
\text { сандр, батальон } \\
\text { «Ивано-Фран- } \\
\text { ковск» } \\
\text { - Семенченко, Се- } \\
\text { мен (Константин } \\
\text { Гришин), бата- } \\
\text { льон «Донбасс» } \\
\text { - Береза, Юрий, ба- } \\
\text { тальон «Днепр» } \\
\text { - Федоренко, Алек- } \\
\text { сандр, батальон } \\
\text { «Полтава-2» } \\
\text { - Яголенко, } \\
\text { Андрий, батальон } \\
\text { «Слобожанщина» }\end{array}$ & 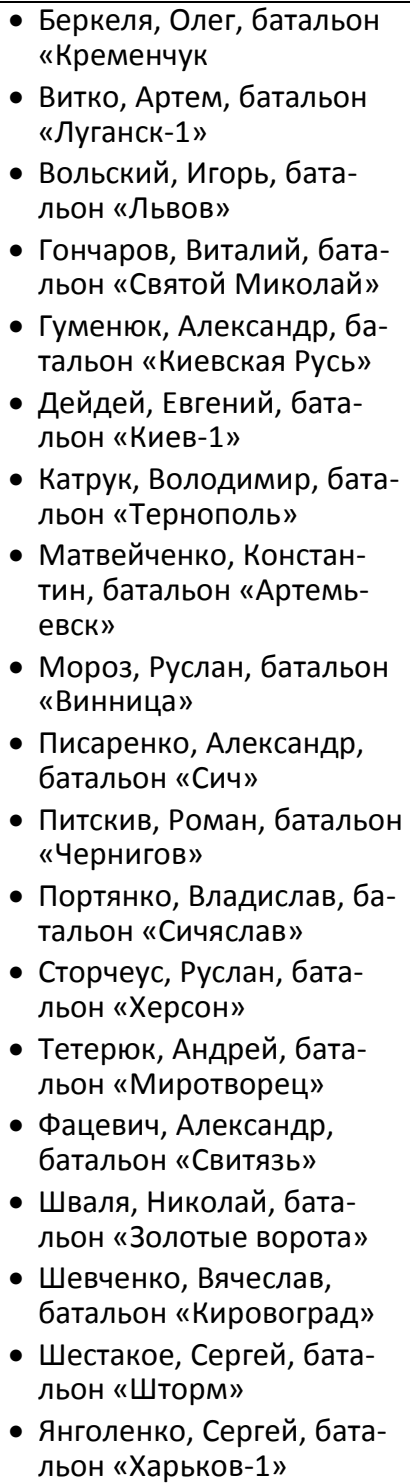 \\
\hline
\end{tabular}




\section{Примеры нетрансферабельных инвестиций}

- Обвинения против других участников батальона, направленные на утверждение собственной власти; примеры: Ирпень и Житомир (2014)

- Нападения на сотрудников МВД в Киеве

- Организация незаконной демонстрации перед Министерством обороны в феврале 2015

- Похищение офицеров и гражданских лиц, грабежи, изнасилования

- Создание рэкетирских банд

- Контрабандный ввоз угля из ДНР

- Предоставление ложной информации официальным СМИ
- Наиболее часто встречающийся пример: командир покидает свой батальон во время Иловайского котла (Битва за Иловайск), чтобы спасти свою собственную жизнь. Такие действия стали причиной гибели многих солдат.
- Исключительно редкие
Основные причины для осуществления нетрансферабельных инвестиций
Ключевые факторы, предотвращающие осуществление нетрансферабельных инвестиций

- Военное образование предотвращает осуществление таких инвестиций, так как оно меняет отношение личности к конфликту

- Дисциплина

- Прошлое участие в жестоких вооруженных конфликтах

установлена сильная связь между командиром и поведением его батальона, т.е. гипотезу 1 можно считать доказанной. Существует дальнейшая связь между социальными характеристиками командира, рассмотренными по методу F-шкалы, и его дальнейшим поведением во время конфликта.

В итоге, можно сказать, что представленная методика дает возможность идентифицировать потенциальных военных преступников, которые готовы делать нетрансферабельные инвестиции в ходе конфликта. У этой 
теории имеются множество практических приложений. Ее можно использовать, чтобы предсказывать, кто прибегнет к нетрансферабельным инвестициям, и таким образом избежать некоторых военных преступлений и уменьшить число жертв в данной конфронтации.

\section{Приложение 1}

Информационные источники для контент-анализа:

1.Официальный вебсайт украинского Министерства обороны, www.mil.gov.ua

2.Официальный вебсайт администрации Генерального прокурора Украины, http://www.gp.gov.ua/

3.Официальная фейсбук страница АTO, www.facebook.com/ato.news

4. Новостное агентство «Герои АТО», http://www.atoheroes.org/

5.Официальная веб-страница АTO, https://urp.ssu.gov.ua

6.Новостное агентство «Обозреватель», http://obozrevatel.com/crime/

7. Новостное агентство «Уновости», http://unovosti.tk/category/rassledovaniya/

8. Новостное агентство ДОСьЕ, http://dosie.su/

\section{Об авторах}

Михаил Комин - студент магистерской программы Высшей школы экономики в Санкт-Петербурге. E-mail: kominmo@уandex.ru.

Александр Вилейкис - студент бакалаврской программы Государственного университета Санкт-Петербурга. E-mail: lexandro.vileykis@gmail.com. 